\title{
Searching for the longevity gene. Where are we heading?
}

\section{Poszukiwanie genu długowieczności. Dokąd zmierzamy?}

\author{
Mariola Głowacka, 2, Beata Haor³, Marta Giezek ${ }^{4}$, Paulina Zabielska ${ }^{4}$, Sylwia Wieder-Huszla5, \\ Katarzyna Karakiewicz-Krawczyk ${ }^{5}$, Katarzyna Barczak ${ }^{6}$, Anna Jurczak ${ }^{5}$
}

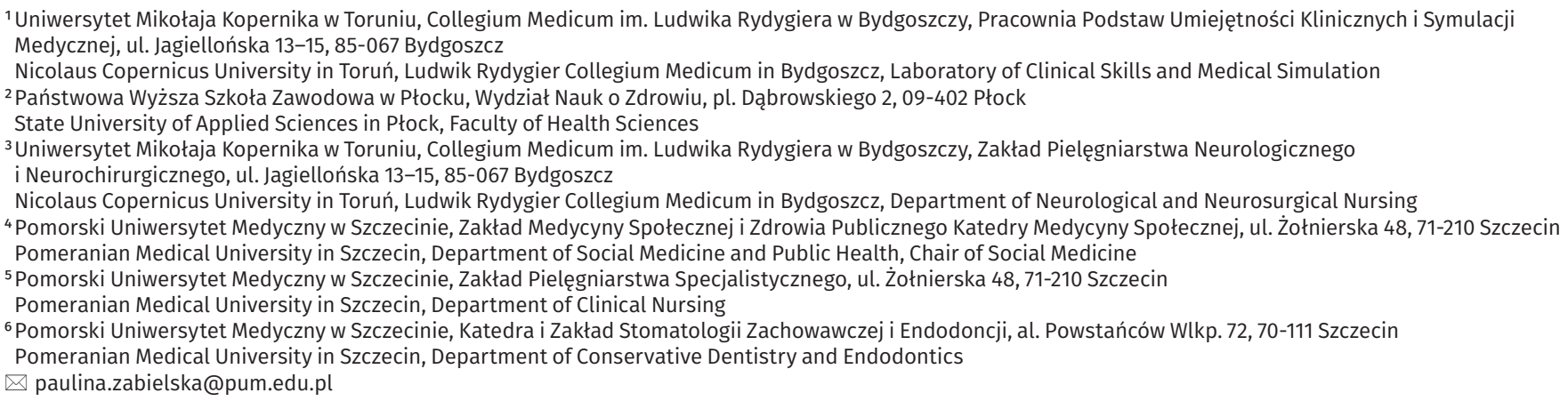

\section{ABSTRACT}

Introduction: Human longevity is a complex phenotype with strong genetic components. Identifying the genetic factors which influence human longevity is a formidable challenge. The centenarian model provides us with a unique opportunity to face this challenge.

The objective of the study was to diagnose the universality of applying studies on polymorphisms favouring longevity in people over 65 years of age.

Materials and methods: Crucial articles were obtained by reviewing and analysing the PUBMED (MEDLINE) database by searching for the following entries: $L E P / r s 7799039, L E P R /$ rs1137100, FOXO1a/rs4943794, CETP/rs5882, TP53/rs1042522, IL6/ rs1800795, ACSL1 rs6552828, THRH/rs7832552, IL6/rs1800795, IGF1R/rs2229765, IGF-IR, IRS-1, FOXO1A, PI3KCB, testosteron (IGF-1) (DHEA-S), FOXO3 (MIM 602681), APOE, HRAS1, LASS1, CETP I4O5 V gene, CETP/rs9923854, APOE/rs769449, IL6/rs2069827, APOC3/ rs2542052, MTP/rs2866164. Article selection was based on inclusion criteria set by the authors and the appointed Advisory Board.
Results: Most of the identified gene variants are specific to a given population. Only a small group of genes consistently show up in various types of studies and in different populations. In humans, the influence of single genes on life expectancy is negligible. What gains significance is a set of genetic variants which favours longevity. There are numerous sets of such genes. Conclusions: The development of a new generation of sequencing techniques makes it possible to comprehend the genetic and epigenetic background of aging. Many researchers believe that aging is inevitable, but to some extent modifiable. Understanding the mechanisms responsible for aging may, in turn, indicate essential avenues of health promotion and disease prevention in middle age, so that elderly people could enjoy good health. Searching for polymorphisms specifically related to longevity enables the identification of new biological pathways connected to the control of life expectancy. Further research in this field could also help in developing more effective ways of treating age-related diseases.

Keywords: genes; longevity; elderly; searching; analysis.

\begin{abstract}
ABSTRAKT
Wstęp: Ludzka długowieczność jest złożonym fenotypem o silnej predyspozycji genetycznej. Identyfikacja czynników genetycznych wpływających na długowieczność człowieka jest prawdziwym wyzwaniem. Model centenariuszy daje nam wyjątkową okazję do stawienia mu czoła.

Celem pracy było zdiagnozowanie powszechności zastosowania badań dotyczących polimorfizmów sprzyjających długowieczności u osób powyżej 65. r.ż.

Materiały i metody: Istotne artykuły uzyskano w wyniku przeglądu i przeanalizowania bazy danych PUBMED (MEDLINE) poprzez wpisanie haseł: $L E P / r s 7799039, L E P R / r s 1137100$, FOXO1a/ rs4943794, CETP/rs5882, TP53/rs1042522, IL6/rs1800795, ACSL1 rs6552828, THRH/rs7832552, IL6/rs1800795, IGF-1R/rs2229765,
\end{abstract}

IGF-IR, IRS-1, FOXO1A, PI3KCB, testosteron (IGF-1) (DHEA-S), FOXO3 (MIM 602681), APOE, HRAS1, LASS1, CETP I405 V gene, CETP/ rs9923854, APOE/rs769449, IL6/rs2069827, APOC3/rs2542052, MTP/ rs2866164. Wybór artykułów był zależny od kryteriów określonych przez autorów i powołane gremium doradcze.

Wyniki: Większość zidentyfikowanych odmian genów jest typowa dla danej populacji. Jedynie niewielka grupa genów konsekwentnie jest odnajdywana w różnych typach badań i u różnych populacji. U ludzi wpływ pojedynczych genów na długość życia jest niewielki. Ważny staje się dopiero „zestaw” odmian genetycznych, który sprzyja długowieczności. Istnieją liczne zestawy takich genów.

Wnioski: Rozwój nowej generacji technik sekwencjonowania umożliwia zrozumienie genetycznego i epigenetycznego 
podłoża starzenia. Wielu badaczy uważa, że proces ten jest nieunikniony, ale do pewnego stopnia modyfikowalny. Obecnie jesteśmy świadkami rozwoju medycyny przeciwstarzeniowej zmierzającej do wydłużania życia. Poszukiwanie polimorfizmów znamiennie związanych z długowiecznością daje możliwość identyfikacji nowych szlaków biologicznych, od których zależna jest kontrola długości życia.

Słowa kluczowe: geny; długowieczność; osoby starsze; poszukiwanie; analiza.

\section{INTRODUCTION}

Human longevity is a complex phenotype with strong genetic components. Identifying the genetic factors which influence human longevity is a formidable challenge. The centenarian model provides us with a unique opportunity to face this challenge. The influence of geography and demographics on the longevity phenotype is of crucial importance, as is the relationship between longevity and homozygosity. The human genome plays a large role in longevity research through the use of new solutions, such as the concept of a complex allele as the basic process of modulating the likelihood of achieving longevity. The average human life expectancy in developed countries is currently approximated at 80 to 85 years. Environmental factors, for instance a chosen lifestyle or place of residence, together with genetic factors contribute to healthy aging $[1,2]$. Lifespan depends mainly, but not solely, on the pace of aging. Longevity is determined by environmental factors, coincidental factors, and gene variants. There are numerous scientific reports outlining methods for testing the influence of genes on life expectancy and these include animal testing, association studies of single gene types, genome-wide association studies, and whole genome sequencing.

In the genome-wide association studies (GWAS), application of microarrays enables detection of hundreds of thousands of SNPs (single nucleotide polymorphisms) simultaneously. In GWAS, genes for analysis are not selected in advance and therefore the study includes all genes.

Intense hunts for longevity genes have been conducted in both animal models and humans. Studies of human families have shown that genetic factors are implicated in a small number of total changes in adulthood (approximately 20-30\%); however, it is not known whether genetic factors become increasingly more important for survival at older ages. Until around the age of 85 , lifespan is only $25-30 \%$ determined by genes $[3,4]$. According to Schoenmaker et al. [5], the situation is different in people over 90 years of age, in whom the role of genetic factors grows significantly and longevity is achieved more easily by people with so-called favourable gene variants. Many epidemiological studies have demonstrated that the parents, siblings, and offspring of long-lived people have a great advantage in survival over the general population. Nevertheless, many of these reported benefits stem from shared genetic factors or shared environment and still need to be fully elucidated. Studies conducted among the population of southern Italy showed that the siblings of centenarians are more likely to live to be 100 years old, but that the parents and siblings of 90 -year-olds also have a better chance of living longer than other people.
This effect may be partially related to gender (stronger in male relatives) [6]. The objective of this study was to diagnose the universality of applying studies on polymorphisms favouring longevity in people over 65 years of age.

\section{MATERIALS AND METHODS}

Crucial articles were obtained by reviewing and analysing the Pubmed (Medline) database by searching for the following entries: LEP/rs7799039, LEPR/rs1137100, FOXO1a/rs4943794, CETP/ rs5882, TP53/rs1042522, IL6/rs1800795, ACSL1 rs6552828, THRH/ rs7832552, IL6/rs1800795, IGF-1R/rs2229765, IGF-IR, IRS-1, FOXO1A, PI3KCB, testosteron (IGF-1) (DHEA-S), FOXO3 (MIM 602681), APOE, HRAS1, LASS1, CETP I405 V gene, CETP/rs9923854, APOE/rs769449, IL6/rs2069827, APOC3/rs2542052, MTP/rs2866164.

A Community Action Board (CAB) was established, comprised of specialists dealing with issues of the elderly and health - a geneticist, a primary health care physician, a medical analyst, a nurse, a public health specialist. A group interview was conducted, during which the authors and the CAB determined the inclusion criteria:

1. articles published between the years 2003-2015,

2. articles written in English,

3. age of tested subjects: $65^{-111}$,

4. at least one polymorphism specifically related to longevity in various populations analysed in the study.

\section{The role of genetic variants in human longevity}

Most of the identified gene variants are specific to a given population. Only a small group of genes consistently show up in various types of studies and in different populations. In humans, the influence of single genes on life expectancy is negligible. What gains significance is a set of genetic variants which favours longevity. There are numerous sets of such genes. In order to support the hypothesis that the genetic influence on extreme longevity increases with advanced age, Sebastiani P. et al. [7] conducted a meta-analysis of 5 studies on centenarians from the USA, Europe, and Japan, which identified 128 polymorphisms specifically related to longevity (with a $6 \%$ risk of error), out of which the Bonferroni correction left only 16 in Caucasian subjects and 6 in Japanese subjects. Whole genome sequencing makes it possible to detect rare gene variants related to longevity. In a large-scale study of over 1000 centenarians, 281 polymorphisms were found, occurring with various frequency in long-lived people and those from the control group. This study did not show a statistically significant difference between centenarians and young controls in the 
TABLE 1. Published studies concerning longevity genes

\begin{tabular}{|c|c|c|c|c|c|c|c|c|}
\hline $\begin{array}{c}\text { Author } \\
\text { (production } \\
\text { year) }\end{array}$ & Country & Gene/SNP & Chromosome & Alleles & Mutation & $\begin{array}{l}\text { Coding } \\
\text { region/ } \\
\text { Non-coding } \\
\text { region }\end{array}$ & Studied group & Control group \\
\hline $\begin{array}{l}\text { Khabour OF et } \\
\text { al. (2010) [16] }\end{array}$ & Jordan & LEP/rs7799039 & 7 & $A G$ & $-2548 \mathrm{C} / \mathrm{A}$ & $\begin{array}{l}\text { promotor/ } \\
\text { exon } 1\end{array}$ & $\begin{array}{l}110 \text { unrelated people } \\
\text { (avg. } 90.2 \text { years) }\end{array}$ & $\begin{array}{l}120 \text { unrelated people aged } \\
20-50 \text { (avg. } 32 \text { years) }\end{array}$ \\
\hline $\begin{array}{l}\text { Roszkowska- } \\
\text {-Gancarz M } \\
\text { et al. (2014) } \\
\text { [17] }\end{array}$ & Poland & LEP/rs7799039 & 7 & $A G$ & $-2548 \mathrm{G} / \mathrm{A}$ & $\begin{array}{l}\text { promotor/ } \\
\text { exon } 1\end{array}$ & $\begin{array}{l}128 \text { people without } \\
\text { diabetes or } \\
\text { myocardial infarction } \\
\text { (avg. } 101.11 \pm 1.19 \text { ) }\end{array}$ & $\begin{array}{l}\text { group I: } 414 \text { young people (aged } \\
\text { 18-45, avg. } 27.1 \pm 7.3 \text { years); } \\
\text { group II: } 226 \text { myocardial } \\
\text { infarction patients (MI) (aged } \\
28-55 \text {, avg. } 46.9 \pm 5.3 \text { years); } \\
\text { group III: } 190 \text { diabetes mellitus } \\
2 \text { patients (DM2) aged } 26-55 \text {, } \\
\text { avg. } 47.2 \pm 5.3 \text { years) }\end{array}$ \\
\hline $\begin{array}{l}\text { Lunetta KL } \\
\text { et al. (2007) } \\
{[18]}\end{array}$ & USA & $\begin{array}{l}\text { LEPR/rs1137100 } \\
\text { FOX01a/rs4943794 }\end{array}$ & $\begin{array}{c}1 \\
13\end{array}$ & AG & Lys109Arg & $\begin{array}{l}\text { exon } 4 \\
\text { intron }\end{array}$ & $\begin{array}{l}1345 \text { people; cohort } \\
(n=258) \text { and offspring } \\
(n=1087) \text { from } \\
330 \text { long-lived families }\end{array}$ & $\mathrm{n} / \mathrm{a}$ \\
\hline $\begin{array}{l}\text { Kolovou G } \\
\text { et al. }(2014) \\
{[19]}\end{array}$ & Greece & CETP/rs5882 & 16 & AG & Val422ILE & exon 14 & $\begin{array}{l}202 \text { people aged } \geq 90-99 \\
\text { (190 people) and } \geq 99 \\
\text { (12 people) }\end{array}$ & $\begin{array}{l}105 \text { people aged from } \\
18 \text { to }<80\end{array}$ \\
\hline $\begin{array}{l}\text { Mustafina OE } \\
\text { et al. (2011) } \\
{[20]}\end{array}$ & Russia & TP53/rs1042522 & 17 & CG & Pro72Arg & exon 14 & $\begin{array}{l}1620 \text { people aged } 21-109 ; \\
\text { including } 212 \text { people } \\
\text { aged } \geq 90 \text { ( } 33 \text { men and } \\
179 \text { women) }\end{array}$ & $\begin{array}{l}\text { group I: aged 22-35 (148 } \\
\text { people); } \\
\text { group II: aged 36-60 (272 } \\
\text { people); } \\
\text { group III: aged 61-74 (348 } \\
\text { people); } \\
\text { group IV: aged 75-89 (640 } \\
\text { people) }\end{array}$ \\
\hline $\begin{array}{l}\text { Fuku N et al. } \\
\text { (2015) [21] }\end{array}$ & $\begin{array}{l}\text { Spain } \\
\text { Italy } \\
\text { Japan }\end{array}$ & $\begin{array}{l}\text { IL6/rs1800795 } \\
\text { ACSL1 rs6552828 }\end{array}$ & 7 & $\begin{array}{l}\mathrm{CG} \\
\mathrm{AG}\end{array}$ & $-174 G / C$ & $\begin{array}{l}\text { promotor } \\
\text { promotor }\end{array}$ & $\begin{array}{l}\text { Study I } \\
138 \text { people aged } 100-111 ; \\
\text { Study II } \\
79 \text { people aged } 100-104 ;\end{array}$ & $\begin{array}{l}\text { Study I } \\
\text { control group: } 334 \text { people aged } \\
\text { 20-50; } \\
\text { Study II } \\
316 \text { people aged } 27-81 ;\end{array}$ \\
\hline & & THRH/ rs7832552 & & $\mathrm{CT}$ & & promotor & $\begin{array}{l}\text { Study III } \\
742 \text { people aged 100-116 }\end{array}$ & $\begin{array}{l}\text { Study III } \\
499 \text { people aged 23-59 }\end{array}$ \\
\hline $\begin{array}{l}\text { Albani D et al. } \\
(2011)[22]\end{array}$ & Italy & $\begin{array}{l}\text { IL6/rs1800795 } \\
\text { IGF-1R/rs2229765 }\end{array}$ & & $\begin{array}{l}\mathrm{CG}, \mathrm{GG} \\
\mathrm{GG}, \mathrm{AA}\end{array}$ & & $\begin{array}{l}\text { promotor } \\
\text { promotor }\end{array}$ & 668 people aged 70-106 & $\mathrm{n} / \mathrm{a}$ \\
\hline $\begin{array}{l}\text { Bonafè M } \\
\text { et al. (2003) } \\
{[23]}\end{array}$ & Italy & $\begin{array}{l}\text { IGF-IR } \\
\text { IRS-1 } \\
\text { FOXO1A } \\
\text { PI3KCB }\end{array}$ & & $\begin{array}{l}G / A \\
G / A \\
T / C \\
T / C \\
A / G\end{array}$ & $\begin{array}{l}+97347 \mathrm{bp} \\
-359 \mathrm{bp} \\
-303 \mathrm{bp}\end{array}$ & $\begin{array}{l}\text { codon } 1013 \\
\text { codon } 972\end{array}$ & $\begin{array}{l}218 \text { people aged } 86-109 \\
\text { (avg. } 98.0 \pm 4.31 \text { ) }\end{array}$ & $\begin{array}{l}278 \text { people aged } 17-85 \\
\text { (avg. } 54.8 \pm 21.5 \text { ) }\end{array}$ \\
\hline $\begin{array}{l}\text { Maggio M et al. } \\
(2007)[24]\end{array}$ & Italy & $\begin{array}{l}\text { testosterone, } \\
\text { (IGF-1), (DHEA-S) }\end{array}$ & & & & & 410 men aged $\geq 65$ & $\mathrm{n} / \mathrm{a}$ \\
\hline $\begin{array}{l}\text { Boyden SE, } \\
\text { Kunkel LM } \\
(2010)[25]\end{array}$ & USA & $\begin{array}{l}\text { FOXO3 (MIM } \\
602681)\end{array}$ & $\begin{array}{c}6 \\
3 p 24-22 \\
9 q 31-34 \\
12 q 244 q 22-25\end{array}$ & & & & 279 long-lived families & $\mathrm{n} / \mathrm{a}$ \\
\hline $\begin{array}{l}\text { Jazwinski SM } \\
\text { et al. (2010) } \\
{[26]}\end{array}$ & USA & $\begin{array}{l}\text { APOE, HRAS1, } \\
\text { dLASS1 }\end{array}$ & & $\begin{array}{l}\text { CCT } \\
\text { CGT }\end{array}$ & & & 147 people aged $\geq 98$ & 188 people aged $20-59$ \\
\hline $\begin{array}{l}\text { Barzilai N } \\
\text { et al. (2003) } \\
{[27]}\end{array}$ & USA & CETP 1405 V gene & & & & & $\begin{array}{l}213 \text { people aged } 95-107 \\
\text { and } 216 \text { people aged } \\
51-89\end{array}$ & 75 people (avg. 70.2) \\
\hline $\begin{array}{l}\text { Soerensen M } \\
\text { et al. (2013) } \\
{[28]}\end{array}$ & $\begin{array}{l}\text { Nether- } \\
\text { lands }\end{array}$ & $\begin{array}{l}\text { CETP/rs9923854 } \\
\text { APOE/rs769449 } \\
\text { IL6/rs2069827 }\end{array}$ & & $\begin{array}{l}A G \\
C A\end{array}$ & & & 563 people aged $\geq 85$ & $\mathrm{n} / \mathrm{a}$ \\
\hline $\begin{array}{l}\text { Novelli V et al. } \\
\text { (2008) [29] }\end{array}$ & USA & $\begin{array}{l}\text { АРОС } 3 / \\
\text { rs2542052 } \\
\text { MTP/rs2866164 }\end{array}$ & & & $\begin{array}{l}-641 C / A \\
-493 G / T\end{array}$ & & $\begin{array}{l}\text { Group I: } 381 \text { people aged } \\
\text { 93-111 (avg. 101.7); } \\
\text { Group II: } 368 \text { people aged } \\
\text { 93-105 (avg. 95.9) }\end{array}$ & 355 people (avg. 27.4) \\
\hline
\end{tabular}


frequency of occurrence of a large number of genetic variants related to diseases. This suggests that favourable gene variants regulating the pace of aging and other processes, e.g. genome function, take precedence over risky variants of disease genes. However, if the risky variants are present, the favourable variants of longevity genes may counteract their negative influence [1]. Numerous studies offer the conclusion that the locus containing genes TOMM4O, APOE, and APOC1 is the one most strongly connected with longevity $[7,8,9]$. A metaanalysis performed by Garatachea et al. on a group of 2776 centenarians and 11941 younger controls showed that there exists a connection between the apolipoprotein E gene (APOE), which encodes a cholesterol transporting protein, and extreme longevity $(E L)$. The conducted studies confirm that apart from its previously-documented influence on the risk of developing Alzheimer's and cardiovascular disease, the APOE gene is connected to the probability of achieving $E L$ [10]. Subsequent studies demonstrate the existence of a relation between the LMNA gene variant and longevity [1]. This correlation is also confirmed by Beekman et al., who performed multi-centre studies on a group of 3448 long-lived people and younger control groups [8]. Another gene related to longevity is the gene encoding the $\mathrm{FOXO}_{3} \mathrm{~A}$ transcription factor, which is the ortholog of the daf- $16 \mathrm{C}$. elegans gene. The $\mathrm{FOXO}_{3} A$ protein is an element of the signaling pathway controlling growth and metabolism and a variant of this gene has been connected with the longevity of people of many nationalities: Japanese, Chinese, Italian, German, and Ashkenazi Jews [11,12]. Chung et al. studied the genes involved in the pathway of insulin and insulin-like growth factor 1: IR, IGF1R, KLOTHO, FOXO (FOXO3A). The authors demonstrated that genetic polymorphisms of insulin/insulinlike growth factor 1 (IIS) signaling pathway components influence human longevity. They also proved that $\mathrm{FOXO}_{3} A$ variants are related to longevity in various human populations and that the variants of genes involved in lipoprotein metabolism and cell cycle regulation contribute to human longevity [13]. These results find confirmation in a meta-analysis of GWAS published in The Journal of Gerontology which included 6036 people $\geq 90$ years of age and 3757 people forming a control group who died when they were between 55 and 80 years of age. This study showed a highly significant correlation between the $\mathrm{FOXO}_{3}$ variant and longevity [14]. In Italian centenarians, in turn, a polymorphism of the gene encoding the IGF-1R receptor was found [15]. Genes affecting life expectancy through modification of the risk of life-shortening diseases include paraoxonase (PON1), the microsomal transfer protein (MTP), and the cholesterylester transfer protein (CETP). The favourable variants of these genes decrease the risk of cardiovascular disease. Other authors also confirm the influence of genetics on human longevity (Tab. 1). The polymorphisms promoting longevity listed by researchers include such genes as: $L E P /$ rs7799039, LEPR/rs1137100, FOXO1a/rs4943794, CETP/rs5882, TP53/ rs1042522, IL6/rs1800795, ACSL1 rs6552828, THRH/rs7832552, IL6/rs1800795, IGF-1R/rs2229765, IGF-IR, IRS-1, FOXO1A, PI3KCB, testosteron (IGF-1) (DHEA-S), FOXO3 (MIM 602681), APOE, HRAS1, LASS1, CETP I405 V gene, CETP/rs9923854, APOE/rs769449, IL6/ rs2069827, APOC3/rs2542052, MTP/rs2866164. These studies were conducted in different countries on large populations of long-lived people or family members of long-lived people. The majority of the subjects were over 90 years of age (Tab. 1).

\section{CONCLUSION}

Research into the polymorphisms favouring longevity helps us to understand the genetic and epigenetic contribution to aging. The development of a new generation of sequencing techniques makes it possible to comprehend the genetic and epigenetic background of aging. Many researchers believe that the aging process is inevitable but modifiable to a certain extent. Presently, we are witnessing the development of anti-aging medicine aimed at life prolongation. Searching for polymorphisms specifically related to longevity enables the identification of new biological target pathways connected to the control of life expectancy. The polymorphisms analyzed in this study are universal and can thus be found in various populations. Understanding the mechanisms responsible for aging may, in turn, indicate worthwhile avenues for health promotion and disease prevention in middle age, so that elderly people could enjoy good health. Further research in this field could also help to develop more effective methods of treating age-related diseases, delaying the aging process, and eventually prolonging human life.

\section{REFERENCES}

1. Sebastiani P, Solovieff N, Dewan AT, Walsh KM, Puca A, Hartley SW, et al. Genetic signatures of exceptional longevity in humans. PLoS One 2012;7(1):e29848.

2. Flachsbart F, Dose J, Gentschew L, Geismann C, Caliebe A, Knecht C, et al. Identification and characterization of two functional variants in the human longevity gene FOXO3. Nat Commun 2017;8(1):2063.

3. Fuku N, Díaz-Peña R, Arai Y, Abe Y, Zempo H, Naito H, et al. Epistasis, physical capacity-related genes and exceptional longevity: FNDC5 gene interactions with candidate genes FOXOA and APOE. BMC Genomics 2017:14;18(Suppl 8):803.

4. Hjelmborg JV, Iachine I, Skytthe A, Vaupel JW, McGue M, Koskenvuo M, et al. Genetic influence in human lifespan and longevity. Hum Genet 2006;119:312-21.

5. Schoenmaker M, de CraenAJM, de Meijer PHEM, Beekman M, Blauw GJ, Slagboom PE, et al. Evidence of genetic enrichment for exceptional survival using a family approach: the Leiden Longevity Study. Eur J Hum Genet 2006;14:79-84

6. Montesanto A, Latorre V, Giordano M, Martino C, Domma F, Passarino G. The genetic component of human longevity: analysis of the survival advantage of parents and siblings of Italian nonagenarians. Eur J Hum Genet 2011;19:882-6.

7. Sebastiani P, Bae1 H, Sun FX, Andersen SL, Daw EW, Malovini A, et al. Meta-analysis of genetic variants associated with human exceptional longevity. Aging 2013;5(9):653-61.

8. Beekman M, Blanché H, Perola M, Hervonen A, Bezrukov V, Sikora E, et al. Genome-wide linkage analysis for human longevity: Genetics of Healthy Aging Study. Aging Cell 2013;12(2):184-93.

9. De Benedictis G, Franceschi C. The unusual genetics of human longevity. Sci Aging Knowledge Environ 2006;10:pe20.

10. Garatachea N, Marín PJ, Santos-Lozano A, Sanchis-Gomar F, Emanuele E, Lucia A. The ApoE gene is related with exceptional longevity: a systematic review and meta-analysis. Rejuvenation Res 2015;18(1):3-13. 
11. Sun L, Hu C, Zheng C, Qian Y, Liang Q, Lv Z, et al. FOXO3 variants are beneficial for longevity in Southern Chinese living in the Red River Basin: A case-control study and meta-analysis. Sci Rep 2015;5:9852.

12. Eisenstein M. Centenarians: Great expectations. Nature 2012;492:S6-8.

13. Chung WH, Dao RL, Chen LK, Hung SI. The role of genetic variants in human longevity. Ageing Res Rev 2010;9(Suppl 1):S67-78.

14. Broer L, Buchman AS, Deelen J, Evans DS, Faul JD, Lunetta KL, et al. GWAS of longevity in CHARGE consortium confirms APOE and FOXO3 candidacy. J Gerontol A Biol Sci Med Sci 2015;70(1):110-8.

15. Kuningas M, Mooijaart SP, van Heemst D, Zwaan BJ, Slagboom PE, Westendorp RG. Genes encoding longevity: from model organisms to humans. Aging Cell 2008;7:270-80.

16. Khabour OF, Mesmar FS, Alatoum MA, Gharaibeh MY, Alzoubi KH. Associations of polymorphisms in adiponectin and leptin genes with men's longevity. Aging Male 2010;13(3):188-93. doi: 10.3109/13685531003657800.

17. Roszkowska-Gancarz M, Kurylowicz A, Polosak J, Mossakowska M, Franek E, Puzianowska-Kuźnicka M. Functional polymorphisms of the leptin and leptin receptor genes are associated with longevity and with the risk of myocardial infarction and of type 2 diabetes mellitus. Endokrynol Pol 2014;65(1):11-6. doi: 10.5603/EP.2014.0002.

18. Lunetta KL, D’Agostino RB Sr, Karasik D, Benjamin EJ, Guo CY, Govindaraju R, et al. Genetic correlates of longevity and selected age-related phenotypes: a genome-wide association study in the Framingham Study. JM. BMC Med Genet 2007;19(8),Suppl 1:A13.

19. Kolovou G, Kolovou V, Vasiliadis I, Giannakopoloulou V, Mihas C, Bilianou H, et al. The Frequency of 4 Common Gene Polymorphisms in Nonagenarians, Centenarians, and Average Life Span Individuals. Angiology 2014;65(3):210-5.

20. Mustafina OE, Nasibullin TR, Erdman VV, Tuktarova IA. Analysis of the Associations of Polymorphic Loci in TP53 and NFKB1Genes with Human Age and Longevity. Adv Gerontol 2011;24(3):397-404.

21. Fuku N, He ZH, Sanchis-Gomar F, Pareja-Galeono H, Tian Y, Arai Y, et al. Exceptional longevity and muscle and fitness related genotypes: a functional in vitro analysis and case-control association replication study with SNPs THRH rs7832552, IL6 rs1800795 and ACLS1 rs6552828. Front Aging Neurosci 2015;7:59.

22. Albani D, Mazzuco S, Polito L, Batelli S, Ongaro F, Gustafson DR, et al. Insulin-like growth factor 1 receptor polymorphism rs2229765 and circulating interleukin-6 level affect male longevicy in a population-based prospective study (Treviso Longevo-TRELONG). Aging Male 2011;14(4): 257-64.

23. Bonafè M, Barbieri M, Marchegiani F, Olivieri F, Ragno E, Giampieri $C$, et al. Polymorphic variants of insulin-like growth factor I (IGF-I) receptor and phosphoinositide 3-kinase genes affect IGF-I plasma levels and human longevity: cues for an evolutionarily conserved mechanism of life span control. J Clin Endocrinol Metab 2003;88:3299-3304. doi: 10.1210/ jc. 2002-021810.

24. Maggio M, Lauretani F, Ceda GP, Bandinelli S, Ling SM, Metter EJ, et al. Relationship between low levels of anbolic hormones and 6-year mortality in older men: the aging in the Chianti Area (InCHIANTI) study. Arch Intern Med 2007;167:2249-54.

25. Boyden SE, Kunkel LM. High-density genomewide linkage analysis of exceptional human longevity identifies multiple novel loci. PLoS ONE 2010;5:e12432.

26. Jazwinski SM, Kim S, Dai J, Li L, Bi X, Jiang JC, et al. Georgia Centenarian Study and the Louisiana Healthy Aging Study. HRAS1 and LASS1 with APOE are associated with human longevity and healthy aging. Aging Cell 2010;9:698-708.

27. Barzilai N, Atzmon G, Schechter C, Cupples AL, Lipton R, Cheng S, et al. Unique lipoprotein phenotype and genotype associated with exceptional longevity. JAMA 2003;290(15):2030-40.

28. Soerensen M, Dato S, Tan Q, Thinggaard M, Kleindorp R, Beekman M, et al. Evidence from case-control and longitudinal studies supports associations of genetic variation in APOE, CETP, and IL6 with human longevity. Age (Dordr) 2013;35(2):487-500. doi: 10.1007/s11357-011-9373-7.

29. Novelli V, Viviani Anselmi C, Roncarati R, Guffanti G, Malovini A, Piluso G, et al. Lack of replication of genetic associations with human longevity. Biogerontology 2008;9(2):85-92. 